\title{
JEZIKOVNI INŠTITUT BRITANSKEGA SVETA
}

$\longrightarrow$

B ritanski svet je v Veliki Britaniji vodilna organizacija za sodelovanje $\mathrm{z}$ drugimi državami kar zadeva izobraževanje, kulturo in tehniko. Cilj te organizacije je oblikovanje dolgoročnih partnerstev po vsem svetu in izboljševanje mednarodnega sodelovanja. Britanski svet deluje v 108 državah, ena izmed njegovih dejavnosti pa je tudi organiziranje zelo kakovostnih in specializiranih tečajev angleščine. Ti potekajo $\mathrm{v}$ posebnih operativnih enotah Britanskega sveta, na t. i. jezikovnih inštitutih, ki jih je po svetu skupaj 102 .

V Ljubljani deluje Britanski svet že od leta 1992, septembra 1995 pa so se uradno začeli tečaji angleščine tudi na jezikovnem inštitutu na Cankarjevem nabrežju. $\mathrm{Na}$ omenjenem inštitutu so, poleg splošnih tečajev angleščine, konverzacije in priprave na izpite univerze Cambridge, uspešno organizirali tudi vrsto specializiranih tečajev za sodnike, tožilce, učitelje angleščine, novinarje, diplomate itd. Da pa ne bi vse potekalo le v Ljubljani, so poleti 1996 organizirali tečaje tudi v Piranu. Zaradi velikega zanimanja za specializirane jezikovne tečaje se je direktor ljubljanskega jezikovnega inštituta, Andrew Glass, odločil, da bodo odprli satelitski inštitut v Portorožu. Tam tečaji sicer potekajo že od oktobra, uradno pa so se začeli 18. decembra 1996.

Jezikovni inštitut Britanskega sveta je uspešen predvsem zato, ker imajo vsi predavatelji visoko izobrazbo, so kvalificirani in izkušeni učitelji, njihova materinščina pa je angleški jezik. Široka mednarodna mreža omogoča izmenjavo učiteljev, izkušenj in učnega gradiva. Navsezadnje prispeva $k$ ekskluzivnosti tudi ugled Britanskega sveta, kar omogoča dostopnost gradiva (npr. učni listi, ki jih uporabljajo kandidati za britanske diplomate), ki je drugim jezikovnim šolam sicer nedosegljivo.

$\mathrm{Na}$ jezikovnem inštitutu organizirajo tudi tečaje za šolarje in maturante, imajo pa tudi bogato ponudbo dodatnih izobraževalnih oblik za odrasle. Redni tečaji potekajo $\mathrm{v}$ popoldanskih urah. Učne metode in oblike sicer niso nekaj posebnega, vendar pa predavatelji pogosto uporabljajo metodo participacije, ki je primerna za mlade in odrasle. To pomeni, da frontalno poteka samo razlaga, snov pa udeleženci utrjujejo samostojno, v parih ali skupinah. Tako so vsi udeleženci tečaja kar se da aktivni. Večina tečajev ne poteka $\mathrm{v}$ učilnici s predavateljem; poleg rednih ur morajo udeleženci opraviti tudi tedenske naloge v Centru za samostojno učenje, ki je v prostorih ljubljanskega jezikovnega inštituta. Tu so na voljo računalniki s CD-ROM-i, priročna literatura, berila, periodika ter avdio- in videooprema. Udeleženci tako brez predavatelja spoznavajo različne pripomočke o gradivu ter se $\mathrm{z}$ lastnim tempom in takrat, ko jim najbolj ustreza, še dodatno jezikovno urijo.

Jezikovni inštitut ni pomemben le za posameznike, ki bi se radi izpopolnili $\mathrm{v}$ angleščini, temveč je pomemben tudi za podjetja, ministrstva in druge organizacije, kjer se pojavljajo potrebe po visoko specializiranih tečajih. Tu

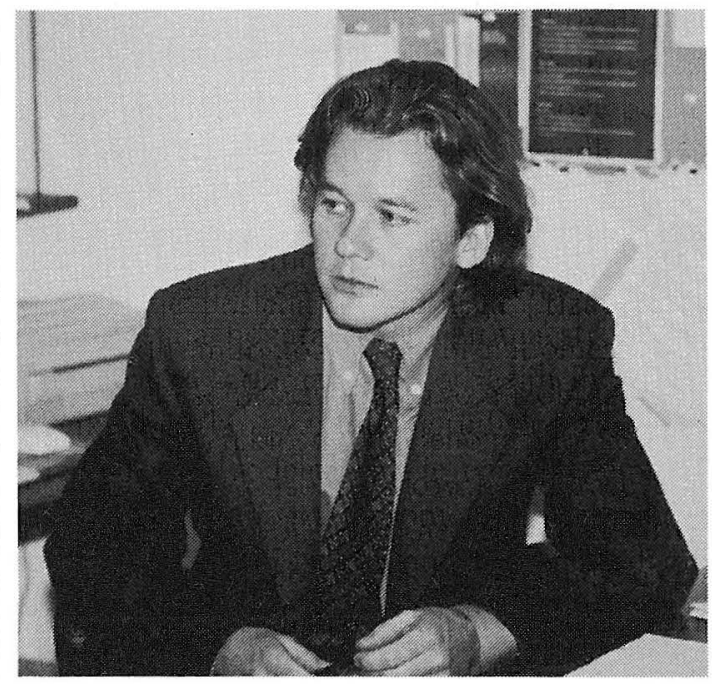

se inštitut izkaže kot fleksibilen in vsestranski izvajalec. Tečaji so lahko prirejeni za posebne potrebe odjemalcev. Lahko potekajo v prostorih inštituta ali pa v prostorih, ki jih določi odjemalec.

Prvi večji projekt jezikovnega inštituta je bila priprava tečajev pravne angleščine za sodnike in državne tožilce na pobudo ministrstva za pravosodje. Tečaji so bili skrbno pripravljeni,

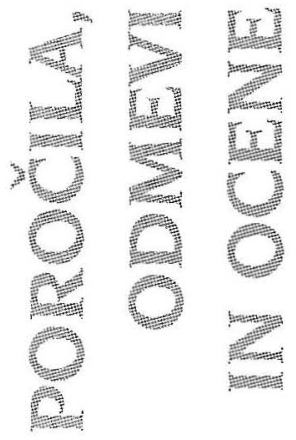

Andrew Glass, direktor jezikounega inštituta Britanskega sveta $v$ Ljubljani 
$\mathrm{z}$ vidika izbire predavateljev ter učnega gradiva in organizacije same. Potekali so na različnih stopnjah $\mathrm{v}$ tedenskih blokih po ves dan, končali pa so se $\mathrm{z}$ dvodnevno delavnico, na kateri so udeleženci na novo pridobljeno znanje tudi praktično uporabili. Za ta projekt so na inštitutu posebej zaposlili učitelja s sedeža Britanskega sveta v Rimu, ki je diplomiral tudi iz prava. Organizirali so tudi obisk pomembnega britanskega sodnika in za popestritev odprli razstavo o britanskem pravnem sistemu. Udeleženci teh tečajev niso le utrdili svojega znanja angleškega jezika in se naučili pravne terminologije, temveč so veliko zvedeli tudi o sami sestavi in delovanju britanskega pravnega sistema. Ta projekt je imel tako velik uspeh, da na inštitutu še zmeraj potekajo tečaji pravne angleščine.

Inštitut že dolgo uspešno organizira tudi tečaje za učitelje angleščine. $\mathrm{Na}$ voljo sta dve vrsti tečajev: prvi je namenjen predvsem metodiki poučevanja angleščine, drugi pa zahtevnejšim in subtilnejšim jezikovnim strukturam ter bogatenju besednega zaklada (tu gre predvsem za spoznavanje izrazov, ki so se $\mathrm{v}$ angleščini pojavili šele pred kratkim). $\mathrm{Na}$ obeh tečajih udeleženci ne izmenjujejo izkušnje le med sabo, ampak tudi s predavatelji. Podobno je s tečaji za novinarje na radiu Koper. Poleg splošne angleščine se udeleženci tečajev urijo tudi $\mathrm{v}$ tehnikah intervjujanja, anketiranja ipd.

Jezikovni inštitut skuša stalno izboljševati ponudbo in kakovost svoje dejavnosti. Direktor inštituta Glass meni, da je Slovenija pravi izziv za ponudnike jezikovnega izobraževanja, saj je splošno znanje angleščine, predvsem pri mladih, na visoki ravni. Vendar pa potrebe po spretnem obvladovanju angleščine pri študiju in delu zaradi globalizacije, širitve Interneta in vseh vrst komunikacije stalno naraščajo. Poudarja tudi, da za posameznika ni dovolj, da zna le nekaj angleščine, če hoče tekmovati na svojem strokovnem področju. Da bi sklenil dobro poslovno kupčijo, predstavil določen proizvod, objavil znanstveno disertacijo ali študiral na tuji univerzi, potrebuje tudi spričevala priznanih institucij, njegov govor mora biti samozavestnejši, pisava pa primernejša. "Naš cilj je, da ostanemo na čelu tega razvoja in da zagotovimo tečaje, ki bodo že danes zadovoljili zahteve, ki nam jih zastavlja jutri, " meni direktor Glass. Hkrati pa ugotavlja, da so tudi odjemalci čedalje bolj zahtevni: hočejo neposredni in osebni pristop ter kvalificirane učitelje, ki bi jim pomagali pri učenju, obenem pa bi jim zagotavljali zanimive in prijetne trenutke zunaj delovnega časa. "Naša dejavnost spada na izobraževalno tržišče, a hkrati tudi na tržišče prostega časa, " povzema direktor Glass.

Jezikovni inštitut Britanskega sveta lahko zadovolji še tako zahtevne odjemalce, ker lahko v razmeroma kratkem času pripravi zelo specializiran tečaj angleščine na katerikoli stopnji. V Sloveniji je uspešen že zato, ker se podjetja in organizacije, pa tudi posamezniki, zavedajo, da je dobro znanje angleškega jezika in poznavanje angleških strokovnih izrazov že nepogrešljivo. Odpiranje svetu pomeni tudi nove zahteve po dodatnem in nenehnem izobraževanju, a tudi vrsto novih možnosti za pridobivanje znanja pri mladini in odraslih. 